\title{
RUSSIA'S REAL SECTOR OF THE ECONOMY: FACTORS AND TRENDS IN H1 2013
}

\author{
O.Izryadnova
}

In the $1^{\text {st }}$ half of 2013, business activity in the Russian economy was determined by weakening of the external demand on goods of the Russian export and moderate growth in domestic demand. A decrease in investments in capital assets and stagnation of manufacturing industries had a negative effect on the domestic market. Growth rates of consumer demand amount to less than 50\% of the indices of the $1^{\text {st }}$ half of 2012. According to evaluations of the Ministry of Economic Development of the Russian Federation, in the $1^{\text {st }}$ half of 2013 GDP growth rates amounted to $1.7 \%$ year-on-year.

In the past six quarters, slow-down of economic growth rates resulted in stagnation of industrial production and a drop in volumes of building and investment activities. In the $1^{\text {st }}$ half of 2013 , the volume of investments in capital assets and the volume of work in building amounted to $98.6 \%$ and $98.1 \%$, respectively, as compared to the respective period of the previous year. As in the past five months financial results of enterprises and entities decreased (in January-May 2013 the balance of profits and losses amounted to $78.3 \%$ on the 2012 figure), opportunities to finance investment programs of economic agents by means of own funds shrank. Investments in capital assets largely rely on state financing; the inflow of direct foreign investments is insignificant. The situation is complicated due to prevalence of the trend of capital flight: in January-June 2013 the outflow of capital amounted to $\$ 38.4 \mathrm{bn}$ (the Ministry of Economic Development of the Russian Federation forecasts the outflow of capital in 2013 at the level of $\$ 30 \mathrm{bn}$ ).

In the $1^{\text {st }}$ half of 2013, a negative effect on economic growth was caused by a drop in the net export; according to preliminary data of the Central Bank of the Russian Federation it fell by $15.6 \%$ as compared to the respective period of 2012. A drop in rates of the export volume in monetary terms was registered in the past three quarters. The import growth rates decrease, as well: from $105.2 \%$ in the $1^{\text {st }}$ quarter to $102.3 \%$ in the $2^{\text {nd }}$ quarter of 2013 as compared to the respective periods of the previous year. Despite a drop in growth rates, the importance of the import in formation of the resources of the economy with low growth rates of domestic production did not diminish. It is to be noted that in the pattern of import some changes started to emerge -- the volumes of import of engineering produce grew at a slower rate than those of the general import, while the import of consumer goods grew at advanced rates.

According to the data of Rosstat, the pattern of utilization of GDP changed towards growth in expendi- tures on ultimate consumption with a decrease in the share of gross savings and net export.

Weak growth in domestic market is underpinned by growth of $3.7 \%$ and $2.0 \%$ in retail trade sales and paid services to households, respectively, as compared to the $1^{\text {st }}$ half of 2012. At the same time, growth rates of consumer demand amount to less than $50 \%$ of the indices of the previous year.

In January-June 2013, the consumer inflation rate amounted to $103.5 \%$ against $103.2 \%$ in 2012 (in June 2013 the inflation rate amounted to $106.9 \%$ year on year against $104.3 \%$ in the respective period of 2012); it is to be noted that prices on food products appreciated at an advanced rate. In the $2^{\text {nd }}$ half of 2013, indexation of regulated tariffs on housing and public utility services will result as in the previous year in further slow-down of retail trade sales.

It is to be noted that in 2013 changes in consumer behavior of households have taken place: households tend to save more with a drop in the share of expenditures on purchases of goods. Also, in June 2013 a trend of weakening of growth in real disposable cash income and real wages and salaries to $102.2 \%$ year-on-year against $106.6 \%$ in 2012 and to $106.0 \%$ against $110.2 \%$, respectively, had a significant effect on the dynamics of consumer demand. In addition to the above, households' credit activities have slowed down, as well.

In the $1^{\text {st }}$ half of 2013 , slow growth rates of the Russian economy point to the diminishing growth potential of the economy. The evidence of the above is the fact that production capacities are loaded at the precrisis maximum level, there are no large-scale investments, production and export of oil have decreased and the level of the unemployment rate is record-low. In the $1^{\text {st }}$ half of 2013 , the gap between the dynamics of the indices of production and demand became larger which situation resulted in growth in warehousing stocks and justified a $0.9 \%$ reduction in transport cargo turnover, including a railway one by $3 \%$ on the respective period of 2012. 
For the first time since 2009, in the $1^{\text {st }}$ half of 2013 industrial production remained at the level of the respective period of the previous year. In the $1^{\text {st }}$ quarter of 2013, stabilization of industrial output was ensured by weak growth of $1.2 \%$ in manufacturing as compared to the respective period of 2012. In the $2^{\text {nd }}$ quarter of 2013 , a change in leaders took place - a $2.7 \%$ growth in production of primary products reversed a $1.3 \%$ drop in manufacturing output.

In manufacturing industry, structural factors had a significant effect on the dynamics of development. In January-June 2013, growth in production remained in low-tech and medium-tech types of economic activities. In production of consumer goods, growth in production of food products, as well as produce of textile and sewing industries was registered. In the segment of goods of intermediary demand, the leaders are production of chemical produce, rubber goods and oil products.

Limitation of the demand has had a considerable effect on the specifics of the dynamics of the high-tech complex of the engineering industry. In the $1^{\text {st }}$ half of 2013 , a $6.5 \%$ drop in production of machines and equipment as compared to the $1^{\text {st }}$ half of 2012 determined weak growth in production of power equipment and electronic and optical equipment that supplies parts for engineering industries of ultimate demand. In the $1^{\text {st }}$ half of 2013 , the index of production of the means of transportation and equipment amounted to $99.3 \%$, including cars (97.3\%), trucks (95.2\%) and buses (97.1\%) of the respective period of the previous year.

For the purpose of support of the domestic auto industry, from July 1, 2013 the Ministry of Industry and Trade of the Russian Federation started the program of state support of car loans on easy terms which measure is to increase the share of purchases on credit from $23 \%$ of the total volume of sales on the basis of the results of the $1^{\text {st }}$ quarter of 2013 to $44-45 \%$ on the basis of the results of the year. The new program of car loans on easy terms suggests subsidizing by the state of the rate in the amount of two-thirds of the rate of refinancing of the Bank of Russia in purchasing by the buyer of a car manufactured by Russian companies or within the frameworks of the agreement on industrial assembly. The minimum amount of pre-payment for a car amounts to $15 \%$ of its cost, while the maximum price of a car, to $\mathrm{Rb} 750,000$ (earlier the maximum price under the program amounted to $\mathrm{Rb} 600,000$ ); the period of repayment of the loan should not exceed 36 months. However, in case of a weak consumer activity even with the above program carried out the sales volumes of new cars and light commercial vehicles may fall by $2-4 \%$ on the basis of the results of 2013 on the 2012 figure.

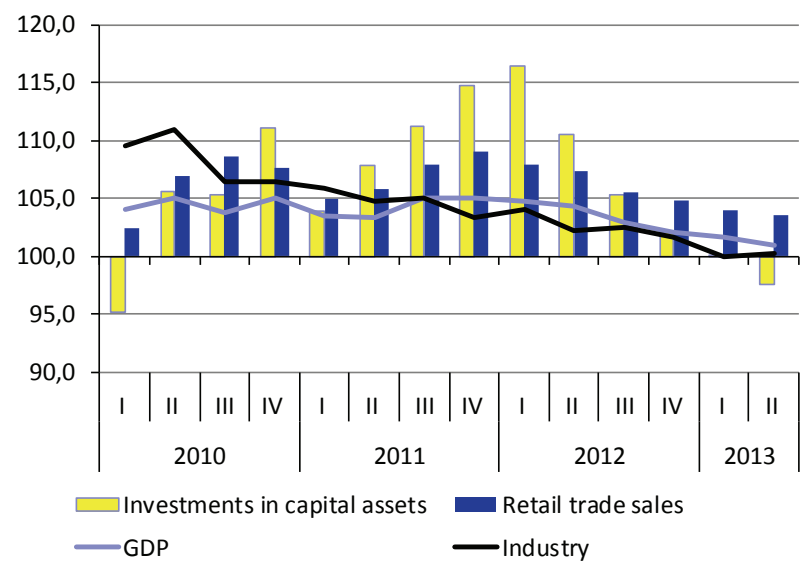

Source: Rosstat.

Fig. 1. Dynamics of the main macroeconomic indices in the 2010-2013 period as \% of the respective quarter of the previous year

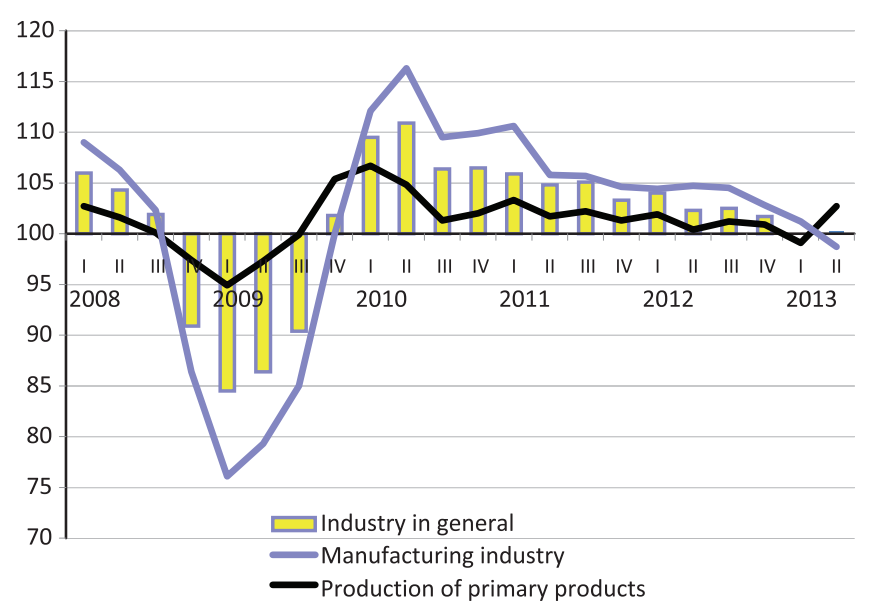

Source: Rosstat.

Fig. 2. Dynamics of industrial production by the type of economic activities in the 2008-2013 period as \% of the respective quarter of the previous year

In the $1^{\text {st }}$ half year of 2013 , on the labor market in general the total number of the unemployed amounted to $96 \%$, while the number of officially registered unemployed, to $83.9 \%$ of the respective indices of 2012 . It is to be noted that the specifics of the past four years is the positive dynamics of growth in employment in the economy despite a steady trend of slow-down of economic growth rates. The above is evidence of low efficiency of labor utilization. The situation is complicated by growing unmet demand in high-skilled labor and structural imbalances. It is to be noted that with advanced growth in labor remuneration in the services sector the process of displacement of labor resources from the commodity producing sector to more profitable types of business activities has intensified.

For the first time since the beginning of 2013, in June the total number of the unemployed rose by $104.7 \%$ and $102.7 \%$ as compared to May 2013 and June 2012, 
PRODUCTION INDICES BY THE TYPE OF ECONOMIC ACTIVITIES IN THE $1^{\text {ST }}$ HALF OF 2009-2011 AS \% OF THE RESPECTIVE PERIOD OF THE PREVIOUS YEAR

\begin{tabular}{|c|c|c|c|c|c|c|c|c|c|}
\hline & \multirow{2}{*}{$\begin{array}{c}2011, \\
1^{\text {st }} \text { half } \\
\text { year }\end{array}$} & \multicolumn{2}{|c|}{ Quarters } & \multirow{2}{*}{$\begin{array}{c}2012, \\
1^{\text {st }} \text { half } \\
\text { year }\end{array}$} & \multicolumn{2}{|c|}{ Quarters } & \multirow{2}{*}{$\begin{array}{c}2013, \\
1^{\text {st }} \text { half } \\
\text { year }\end{array}$} & \multicolumn{2}{|c|}{ Quarters } \\
\hline & & Q1 & Q2 & & 1 & 2 & & 1 & 2 \\
\hline Industries & 105.3 & 105.9 & 104.8 & 103.1 & 104.0 & 102.3 & 100.1 & 100.0 & 100.3 \\
\hline Production of primary products & 102.5 & 103.3 & 101.7 & 100.9 & 101.9 & 100.4 & 101.0 & 99.1 & 102.7 \\
\hline $\begin{array}{l}\text { Production of fuel and en- } \\
\text { ergy primary products }\end{array}$ & 100.8 & 100.3 & 101.4 & 101.5 & 102.3 & 100.4 & 100.8 & 99.5 & 102.1 \\
\hline $\begin{array}{l}\text { Production of primary products, } \\
\text { except for fuel and energy ones }\end{array}$ & 106.2 & 107.7 & 104.3 & 99.9 & 101.5 & 98.3 & 102.1 & 98.8 & 105.0 \\
\hline Manufacturing industries & 108.0 & 110.6 & 105.8 & 104.5 & 104.4 & 104.7 & 100.0 & 101.2 & 98.7 \\
\hline $\begin{array}{l}\text { Production of food products, } \\
\text { including drinks and tobacco }\end{array}$ & 101.2 & 101.7 & 100.5 & 106.4 & 106.2 & 106.0 & 100.7 & 101.3 & 100.1 \\
\hline Textile and sewing industries & 105.3 & 107.7 & 102.8 & 94.6 & 93.2 & 95.9 & 101.8 & 102.3 & 101.3 \\
\hline $\begin{array}{l}\text { Production of leather, leather } \\
\text { articles and footwear }\end{array}$ & 110.3 & 112.8 & 107.8 & 87.8 & 89.8 & 85.8 & 96.4 & 102.8 & 89.9 \\
\hline $\begin{array}{l}\text { Woodworking and produc- } \\
\text { tion of wood articles }\end{array}$ & 106.6 & 106.9 & 106.2 & 102.5 & 100.7 & 103.3 & 97.7 & 101.8 & 93.6 \\
\hline $\begin{array}{l}\text { Pulp and paper production; pub- } \\
\text { lishing and polygraphic activities }\end{array}$ & 100.0 & 99.5 & 100.5 & 106.0 & 107.3 & 103.9 & 92.1 & 91.0 & 93.2 \\
\hline $\begin{array}{l}\text { Production of charred } \\
\text { coal and oil products }\end{array}$ & 103.9 & 104.6 & 104.8 & 102.2 & 102.3 & 103.8 & 101.6 & 100.4 & 102.8 \\
\hline Chemical industry & 106.9 & 108.0 & 105.8 & 101.1 & 99.4 & 102.0 & 103.3 & 102.8 & 103.7 \\
\hline $\begin{array}{l}\text { Production of rubber } \\
\text { and plastic articles }\end{array}$ & 118.0 & 120.6 & 115.4 & 103.2 & 102.8 & 104.4 & 107.8 & 109.4 & 106.1 \\
\hline $\begin{array}{l}\text { Production of other non- } \\
\text { metallic mineral products }\end{array}$ & 111.0 & 112.7 & 109.3 & 108.5 & 112.7 & 106.6 & 102.2 & 102.2 & 102.2 \\
\hline $\begin{array}{l}\text { Metallurgical production and pro- } \\
\text { duction of finished metal articles }\end{array}$ & 103.0 & 109.1 & 96.5 & 106.0 & 104.8 & 107.2 & 99.1 & 102.6 & 95.7 \\
\hline $\begin{array}{l}\text { Production of machines } \\
\text { and equipment }\end{array}$ & 111.8 & 111.6 & 113.2 & 104.4 & 119.8 & 88.1 & 93.5 & 92.3 & 94.8 \\
\hline $\begin{array}{l}\text { Production of power, elec- } \\
\text { tronic and optical equipment }\end{array}$ & 106.5 & 106.3 & 107.8 & 106.1 & 110.6 & 101.2 & 94.7 & 95.5 & 94.8 \\
\hline $\begin{array}{l}\text { Production of transport } \\
\text { means and equipment }\end{array}$ & 134.9 & 159.6 & 115.1 & 121.0 & 122.7 & 129.5 & 99.3 & 95.3 & 103.3 \\
\hline $\begin{array}{l}\text { Production and distribution } \\
\text { of power, gas and water }\end{array}$ & 100.2 & 99.0 & 101.9 & 101.8 & 102.6 & 100.8 & 99.3 & 99.0 & 100.8 \\
\hline
\end{tabular}

Source: Rosstat.

respectively, and amounted to $5.4 \%$ of gainfully occupied population ( $4.1 \mathrm{~m}$ people). The positive aspect is a decrease in the number of the unemployed registered with the employment services: their number amounted to $86.1 \%$ on the June 2012 figure. As of the end of June, the need of employers in workers - declared at the state employment service - amounted to $1.98 \mathrm{~m}$ jobs and increased from the beginning of the year by 555,000 job vacancies. In June 2013 , the rate of tension on the labor market - the number of the unemployed per 100 job vacancies declared at the employment service amounted to 57 persons against 72 persons a year earlier.

According to evaluations of the Ministry of Economic Development of the Russian Federation, in the $1^{\text {st }}$ half year of 2013 the GDP growth rates amounted to $1.7 \%$ year-on-year, including $101.6 \%$ year-on-year in the $1^{\text {st }}$ quarter and $101.9 \%$ year-on-year in the $2^{\text {nd }}$ quarter. Thus, economic growth remains below the official forecast for 2013 at the level of $102.4 \%$. 